Journal of Social Sciences 8 (3): 350-363, 2012

ISSN 1549-3652

(C) 2012 Science Publications

\title{
The Impact of the Professional Learning and Psychological Mentoring Support for Teacher Trainees
}

\author{
Christina Peter Ligadu \\ School of Education and Social Development, \\ University of Malaysia Sabah, Jalan UMS, 88400 Kota Kinabalu, Sabah, Malaysia
}

\begin{abstract}
Problem statement: Mentoring practices have been an important part of the practicum in initial teacher training. The purpose of this study was to investigate the impact of a mentoring program for teacher mentors and mentees. It also explored the factors that influenced the impact of the mentoring program. This study was conducted in two secondary schools in the state of Sabah, Malaysia. Approach: Nine mentees and twelve teacher mentors participated in the study. A qualitative, case study was utilized to investigate the impact of the mentoring program and the factors that influenced the impact. Combined data sources from semi-structured interviews, focus group discussion and document review were used to gather data the in mentoring experiences in the study. Results: The results indicated that the impact of the program was varied but generally positive for both mentees and mentors, professionally and personally. Factors that impacted the mentoring program identified were classroom practices support, peer mentoring, mentoring relationships and interpersonal communications, personal qualities and attitudes, reflective practices and teaching observations. Major constraints identified were availability of mentors, particularly and mentees, time and timing and negative personal qualities and communication skills of both mentors and mentees. Cultural factors also seem to have influenced of the mentoring process. Conclusion: The study overall provides insights and guidelines for modifications to the revised mentoring program and recommendations for SESD, UMS, schools, higher education institutions and education policy makers and for further research.
\end{abstract}

Key words: Mentoring relationships, teacher mentors, mentees, professional and psychological mentoring support

\section{INTRODUCTION}

In recent years teacher mentoring has emerged in many countries, such as the United States of America, Australia, Britain, Europe and Asia, as a common response of school authorities to the needs of new teachers at both the preservice and induction levels (Ismail, 2001; Jonson, 2008; Wang and Odell, 2002). As a consequence, numerous models and programs within teacher education have been developed to provide guidelines for mentoring support. Some studies have been conducted on mentoring in Malaysian schools and higher education institutions. Most of the research has focused on the relationships between mentors and novice teachers (Furlong and Maynard, 1995); the problems faced by school administrators managing mentors and novice teachers, especially in the first year of teaching (Cullingford, 2006); partnerships in mentoring between schools and institutions of teacher training to facilitate the mentoring system during the practicum (McIntyre et al., 1994); career development and advancement in higher education (Ismail and Akrokisamy, 2007); and university students mentoring students in selected schools in the teaching of science and mathematics (Idris, 1999). $\mathrm{Ng}$ and Osman (1995) indicated that there were problems faced by mentees during the practicum as a result of lack of support by teacher mentors. Some of the practicum environments were not conducive to professional development and there was lack of commitment towards the practicum (Tan and Hamid, 1992; Salleh, 1999). Achievement of some of the goals of the induction mentoring programs conducted in schools was constrained, by various factors (Narayanasamy, 1995). Salleh and Hoon (1997) indicated that there was an increasing trend towards greater involvement of schools in the training of preservice teachers either in relation to new teachers or student mentees in teacher training colleges and universities in Malaysia. Tuah (2003) observed that 


\section{J. Social Sci., 8 (3): 350-363, 2012}

mentoring promotes collaboration, cooperation and teamwork between schools and university. Ismail (2001) studied the mentoring system in teacher training institutions in Malaysia that focused on ESL primary school student teachers. She found that mentoring had some influence on mentees' performance but there was still a need for more appropriate training of the mentor teachers. This suggested a need for better ways of mentoring during teaching practicum that would improve on the existing systems. To date, the findings on the effectiveness of the mentoring systems in schools in Malaysia have not been conclusive (Kunjambu et al., 2002) and there are still many grey areas in mentoring that need to be explored and investigated further, specifically focusing on the readiness of mentors for their mentoring roles (Sanggura, 1998; Ismail, 2001). However, Salleh and Hoon (1997) indicated that mentoring is still new and still not fully understood in Malaysia. Hence, more studies are needed to gain better insights into the effectiveness of mentoring in initial teacher education and its impact on mentees.

The main purpose of this research was to implement and investigate the impact of the professional and psychological mentoring support in two secondary schools in Sabah. A mentoring program for teacher trainees was developed focusing on specific areas to meet the needs of teacher mentors and mentees during the practicum. The purpose of conducting this program was to improve and enhance current mentoring practices in schools during the teaching practicum. Mentoring of mentees in the practicum is conceived as essentially an interactive process which is generally concerned with achieving the objectives specified for the practicum. More particularly, it is concerned with facilitating the learning and development of mentees in planning and improving teaching performances. The School of Education and Social Development, University Malaysia Sabah (SESD, UMS) faces many challenges in the teaching practicum. Currently, there is no consistent mentoring system in the teacher training program at the SESD, UMS. The common practice is to invite school principals or school representatives to attend a couple of hours of briefing on the procedures of the teaching practicum. Such a briefing would typically cover topics on practicum procedures and supervision and include discussions on completing evaluation forms and the grading system. To date, there has been no formal training for the roles of mentors and mentees, for example in providing practical teaching knowledge, sharing methods and materials, observation, planning, organizing, personal (emotional) support and reflective teaching. Often, there is a lack of communication and interaction amongst school mentors, mentees and university supervisors in the supervision and assessment of mentees. The need to improve the current mentoring practice by working closely to build rapport with school management and especially with teacher mentors is imperative.

The notion that the practicum course is where the mentees are able to apply their theoretical knowledge in practice makes the SESD, UMS very much aware of the importance of providing mentoring support from both university supervisors and teacher mentors. The two strands of mentees differed in their needs, levels of expectations and teaching confidence and skills during the practicum. Matching of teacher mentors and mentees was seen as an important aspect of the mentoring process. As the selection of school mentors is done by the school principals, there have been cases in which the school's criteria in selecting the school mentors did not match those of the university. Moreover, a majority of the mentors have been unsure of their specific mentoring roles (Ligadu et al., 2001). Furthermore, the enrolment of teaching mentees in Malaysia between 2000 and 2005 increased especially at SESD, UMS. The move made by the Ministry of Education in Malaysia to have graduate teachers in secondary schools and eventually in primary schools, has resulted in an increasing number of teachers entering the university to upgrade their qualifications (SESD, JPPG Report, 2005). With the increasing number of mentees in the practicum and the shortage of lecturers at SESD, UMS to supervise them, measures were increasingly taken to make sure that adequate support would be provided to mentees during the practicum. Among these, the SESD, UMS opted to make the practicum more school-based with the schools playing a major role in mentoring the mentees. The number of teaching observations was also reduced to five by the school and three by university supervisors. The involvement of the university supervisors will continue to include visiting, mentoring and assessing mentees in the schools. The involvement of the teacher mentors became so critical in this practicum that support for teacher mentors needed to be enhanced and optimized to assist the SESD, UMS to maintain the quality of teacher training. These challenges faced by SESD, UMS clearly indicated that there was need for a formal and systematic mentoring program to train both mentors and mentees. For these reasons and guided by a review of literature, the researcher deemed it 


\section{J. Social Sci., 8 (3): 350-363, 2012}

appropriate to develop, implement and investigate the impact of the appropriate mentoring program to provide both the professional learning and psychological mentoring support during the teaching practicum.

Mentoring support: According to Feiman-Nemser (2003) it is wrong to consider beginning teachers as finished products, thinking that they are able to carry out their task without any difficulties. Some studies have indicated that the teaching profession requires beginning teachers to do the same work as experienced teachers (McIntyre and Hagger, 1996). Such responsibilities include adjustment to school environment, routines, policies, procedures and familiarity with curriculum, instructional strategies and classroom management structures and procedures. Some student teachers find this a traumatic experience especially those without any teaching experience in the teaching practicum (Ismail, 2001). Giving support to mentees at this time is crucial to enable them to make a smooth transition into the real situation of teaching and reduce the experience of reality shock when faced with the challenges of the teaching practicum. Hence, the support from mentors provided to new teachers varies to meet their different needs (Villani, 2002). " Mentoring support for beginning teachers has become part of a broad movement in improving teacher education" (Evertson and Smithey, 2000). There are two types of support involved in the teacher mentoring process identified as essential: professional learning support and psychological support. Ganser (1994) argued that the central mentor's role is to provide both types of support. Both are important components in an effective mentoring process (Stansbury and Zimmerman, 2000).

Professional learning support: Professional learning support fosters an understanding of teaching. Jonson (2008) referred this as direct assistance and stated that this support is more useful than other mentoring functions. This kind of support focuses on the basics of daily teaching, from locating materials and other resources available in the school to organizing classroom space and instructional strategies (Kajs, 2002). Learning to teach has become more complex (Hargreaves and Fullan, 2000; McIntyre and Hagger, 1996) and multifaceted. Not only do teachers face the challenges of integrating information and communication technologies, they have the challenge of managing a diversity of learners from different backgrounds and with special needs (Hargreaves and Fullan, 2000). As Hargreaves and Fullan (2000) observed, support from mentors enables mentees to develop their competence and understanding and helps them to "fit in" (p. 52). Without the help of mentors, many novice teachers have difficulty adapting what they learned in the university education courses to their teaching in schools (Jonson, 2008). Cochran-Smith and Lytle (1999) indicated that collaboration between teacher mentors and mentees promoted and generated new knowledge for learning to teach.

Hence, a teacher mentor needs to be competent in subject matter as well as the relevant skills and knowledge for advancing students' learning in the classroom.

Psychological support: Psychological support involves providing emotional or personal support. Underpinning this support are the personal qualities and attitudes of mentors and mentees. Psychological or emotional support is one of the strongest and important needs of beginning teachers (Johnson, 2007; Tickle, 1991) in particular during the practicum where teaching is considered an emotional experience. Johnson (2007) suggests that psychological or emotional support is particularly important in the eyes of mentees and argues that "consistent support creates a safe climate in which students can take risks and do the work of developing personally and professionally" (Johnson, 2007). Such support is needed to reassure and guide beginning teachers and to reduce their anxieties and frustrations with in the current demanding classrooms. It seems that a nurturing environment that meets personal and emotional needs results in mentees being better able to meet their daily demands and challenges (Kilburg, 2007).

Psychological support that makes novices feel comfortable and addresses their personal and emotional needs in the classroom includes such things as providing moral support and suggesting ways in which to balance the demands and expectations of students and teachers in the new environment. It involves assisting in building self-concept and self-esteem, good communications, positive interactions and effective listening skills and caring personalities. Teacher mentors who work along with novices effectively have been found to be those who interact directly in helping and facilitating teaching processes, helping in the construction of teaching and learning situations and providing emotional and professional learning support (Wang and Odell, 2002). Incorporating the humanist element in teacher mentoring is crucial in providing positive direction for personal and professional development as the humanist approach recognizes that every individual has the potential to be self-directing under the right conditions. These conditions include openness to the possibility of change and growth, willingness to break old habits and try out alternatives, 


\section{J. Social Sci., 8 (3): 350-363, 2012}

commitment to deepening self-knowledge and involvement in non-directive, developmental and collaborative approaches (Yost, 2002). Both professional learning and psychological support are important in ensuring the success of the mentoring process especially for mentees who discover an array of new responsibilities during the practicum.

\section{MATERIALS AND METHODS}

This study was conducted in two secondary schools in the state of Sabah, Malaysia. A qualitative, case study approach was used to obtain the perceptions of the teacher mentors and mentees. A purposive sample of twelve teacher mentors and nine mentees participated in this study. The first phase of the study involved examining existing mentoring models and mentoring literature and conducting a short survey to get preliminary feedback on existing mentoring practices in order to develop a mentoring program specifically to provide the professional learning and psychological support. The second phase of the study involved the implementation of the mentoring program and investigation of factors which influenced both of these support. Incorporated in the mentoring program were two mentoring workshops carried out separately for selected teacher mentors and mentees to provide training prior to the teaching practicum. During the implementation of the mentors' workshops at the schools, the mentees also participated in activities which allowed teacher mentors and mentees to socialize and interact with each other.

Semi-structured individual interviews, focus group discussions and document reviews were the primary data collection methods used to examine and analyze the experiences of the teacher mentors and mentees during the practicum. In this study, the researcher chose to analyze reflective journals and practicum guidelines to supplement interview and focus group discussion data. The constant comparison approach was used to code the data and triangulation of the different data sources was employed to discover commonalities and differences and the consistency and ensuring the trustworthiness of the findings. Member checking was also employed to ensure the credibility of the interpretations of data. The theoretical framework of this study was based on selected, relevant theories underpinning the different mentoring models and programs such as Furlong and Maynard's Apprenticeship, Competence-based and Reflective mentoring models (Furlong and Maynard, 1995); (Anderson and Shannon, 1988)'s model; the Knowledge Building Community model (Cambourne et al., 2003);
Furlong and Maynard's Staged Mentoring Model (Brooks et al., 1997); Clinical Supervision Model (Goldhammer et al., 1980); the Humanistic approach, the Situated Apprenticeship approach and the Critical Constructive Theory approach (Wang and Odell, 2002).

\section{RESULTS}

The overall impact of the professional learning and psychological support in this mentoring program was varied but generally positive for both mentees and mentors. Both teacher mentors and mentees, extended the range of their instructional strategies and skills, observing teacher mentors teaching, collaborative team teaching, their lesson planning, their classroom management skills and peer mentoring. Most mentees agreed that their positive development in their professional areas was due to both professional learning and psychological mentoring support provided by mentors in their roles as a guide and advisor and to the mentors' knowledge of content and pedagogical experience. Professionally, the mentors also gained from the program in the development of insights into their own teaching and class management ability; their ability to plan in discussion; their use of questioning and their use of resources. They also gained in selfawareness; communication skills, use of positive reinforcement; relationship building communication skills, interpersonal skills; reflective abilities and in specific skills and techniques in approaching and working with individual mentees:

It should be emphasized here, however, that positive professional development of mentees occurred throughout the practicum, though varying in degree, was clearly evident. Mentors' guidance and advice on pedagogic maters such as planning, instructional skills, knowledge and organization of content and resources and classroom management were major contributors to this development despite any negative factors in mentoring relationships and communication. Mentors' professional experience, though varied and content knowledge were significant factors in this areas.

Teaching resources: Provision of teaching resources varied, with some mentees being provided with adequate resources by mentors, others having to rely on their own initiative or the assistance of fellow mentees in this area.

Most of the mentees were able to develop their teaching knowledge and skills and improved their performance through working, if not teaching, collaboratively with their mentors. The mentees in general agreed that availability of resources such as subject syllabuses, text books, teaching materials, 
reference books, stationery including papers, markers, rulers, transparencies, Liquid Crystal Display (LCD), computer laptops, apparatus and materials for experiments, name lists of pupils, timetables, school calendars and school policy guidelines and rules were most important in the first week of the practicum to enable them to plan, organize and implement their weekly lesson plans. Through this collaboration, mentors too seem to have gained personally and professionally. Mentees also gained in their ability to use resources as aids to instruction and in their knowledge and understanding of schools culture and policies and generally became more reflective, selfcritical and self-reliant, more autonomous particularly in later mentoring phases of the practicum. As pointed out by one of the mentees:

Without the teaching support, a lot of things may not have worked out for me. I want to teach properly and effectively because it is important for me to pass this practicum and achieve the stated competencies in the practicum assessments. Now I realize that I would have been helpless if my teacher mentors did not provide this support. They provided me the help I needed for good teaching. I also found out that you had to be brave to ask for help so that the mentors knew what you needed. This is why my friend did not get this support adequately. She had to get things done on her own. I sympathized with her.

Delays in providing teaching resources were particularly disappointing and caused unnecessary anxiety and reduced some mentees' ability to teach effectively especially during the initial phase of the mentoring program. However, it also enabled these mentees to show more initiative, be less dependent on their mentors and obtain support from other sources, especially their peers. One of the mentees remarked:

My teacher mentor did not furnish me with information on where to get the teaching aids for my teaching. I realized after a while that there was no point in waiting. I got the help from my peers by sharing common teaching resources and also from other mentors.

Availability of teacher mentors: To provide optimum mentoring support, mentors need to be readily accessible for their mentees throughout the program. The availability of participants, particularly mentors, for planning discussions, teaching observations (supervision) and reflective practices was a major factor in the mentoring program. The findings show that the degree of availability of the teacher mentors here had an impact on the development of mentoring relationships. During focus group discussions, the mentees indicated that meeting face-to-face with their teacher mentors had frequently been an important factor in establishing the mentoring relationship. One mentor agreed that it was one of his "....utmost priorities to be always there for my mentee". Half of the mentees spoke of limitations in this area: of inadequacy of time for such activities or the inappropriateness of combining mentoring functions; and of unsatisfactory venues for such activities, with negative consequences for the mentoring process. One of the mentees expressed this in her reflective journal:

Like he is there but he is not there. Very difficult. I think this too affected me trying to build the mentoring relationship with my teacher mentor.

School activities such as the need to attend urgent meetings, ad hoc school activities, or for personal reasons (sick leave) and other demands on mentors' time were given as reasons for their limited availability in the mentoring process. Kilburg (2007) suggested that the greatest obstacles to successful mentoring often lie within the structure and organization of the school especially in terms of when beginners and mentors can spend time together, in informed conversations or the working environment and how physically accessible they are to one another. Mentors' availability to sustain regular, ongoing and continuous support is vital to the successful teacher mentoring process (Rowley, 1999). Nevertheless, the mentors generally made it clear that they tried to be available for their mentees during the mentoring program. In some cases, some mentees reported that the teacher mentors even used text messaging through mobile telephones to inform them if they were not available. These mentees said they were appreciative of such gestures by their mentors because they knew what to do in their absence.

Observations of teacher mentor teaching and team teaching: The main purpose of observing mentors teaching was to give mentees opportunities to see teaching in context, particularly in the big classes of 50 students typical in most of the schools in this area. This was another important means of mentees gaining knowledge and ideas on teaching during the mentoring program: it was not intended to assess or evaluate the 


\section{J. Social Sci., 8 (3): 350-363, 2012}

mentor's lesson. Five mentees had the opportunity for such observations here. One of the mentees said:

My teacher mentor and I talked about what to observe. Observing my teacher mentors gave me better insights into teaching and learning. I could really learn by seeing them teaching, just as they had advised me. They really have the experience to handle the class. I employed what they did and found out some of the techniques worked, not all. It is a learning process.

Another mentee was particularly interested to see how her minor teacher mentor led the class during practical work in the science laboratory:

It gave me ideas of how to control a big class doing experiments in the science lab. I learned when to catch the pupils' attention and when to use a loud voice rather than yelling most of the time. Observing him teaching helped me a lot in my own teaching.

Through observations, mentees learned to use different teaching strategies, increased their confidence in teaching and learned how to manage the classroom especially, in the science laboratories and how to use interpersonal skills in communicating with pupils. Not all of the mentees who observed their mentors benefited from it. Two mentees reported that they did not really learn much from observing their teacher mentors teach and that this was because the mentors had not emphasized it. These mentees were not convinced of the worth of observing their mentors and were not keen to do so. They concluded that planning and discussing pedagogical knowledge, strategies and content with their teacher mentors were more useful. One of the mentors pointed out:

My mentee asked me once but she did not really make it a point to observe me. She would not observe me, anyway. I told her she could come and observe me any time.

Some teacher mentors in this study were not keen to be observed by their mentees. They argued that the other supports provided were sufficient and that observed teaching might not conform to the mentee's teaching styles. Perhaps, however, they were merely uncomfortable at being observed by mentees. This aligned with the studies that suggest some teacher mentors resist the idea of being observed by their mentees for fear of being judged (Cullingford, 2006). Similarly, Ismail (2001) indicated that teachers in Malaysia generally were not keen to be observed during the practicum. Perhaps, such reluctance could be a matter of preference and for privacy of and independence (Cullingford, 2006). Nevertheless, one positive outcome in this study was that mentees took the initiative to observe other teacher mentors, to solve their own problems, independently of their assigned mentors.

Collaborative teaching, or team teaching, in this study involved the mentees teaching part of the lesson alongside their teacher mentors. Its basic purposes were to allow mentees to become gradually familiar with teaching in a real situation, to create an environment that was non-threatening and to boost the confidence of the mentees. This also involved planning the lesson together with the mentor and it occurred only in the first two weeks of the mentoring program:

At first, it bothered me to be teaching together but I learned more when I watched as my teacher mentor did the experiments with the pupils. My teacher mentor's input was beneficial. It was good for me especially as I do not have teaching experience. I learned a lot from this experience

The findings indicate that not all of the mentees benefited from collaborative team teaching support, despite this approach being advocated in the mentoring program as one of the ways that mentees could gain access to the approaches of experienced teachers' in classroom practices (McIntyre and Hagger, 1996). It was obvious that mentors were not keen to implement this component because of such factors as in time constraints, other school activities and mentees' previous teaching experience. At the same time, there were some mentees who were not keen to teach collaboratively. Perhaps such reluctance could be due to lack of trust and fear of loss of self-esteem which prevented both mentors and mentees engaging in collaborative teaching (Cullingford, 2006). In order for collaboration outcomes to be successful, such teaching must be approached with a positive attitude (Moore and Wells, 1999).

Peer mentoring: Peer mentoring, in fact, became an important part of the program for most mentees, particularly where mentors were perceived to provide only limited support. Additional help and support from peer mentoring was a significant feature of this study and was added to the mentoring program to assist mentees in their professional development. However, 


\section{J. Social Sci., 8 (3): 350-363, 2012}

mentees had mixed perceptions on peer mentoring. All the mentees (in focus group discussion) found peer mentoring helpful in assisting them daily in their lesson plans, teaching techniques, strategies, content, teaching aids and classroom management skills. In general, they agreed that peer mentoring was particularly needed during the initial phase of the mentoring program. To them, this phase was a period of adjusting to a new environment and peer mentoring played a vital part here in addition to the major roles played by teacher mentors. For some, peer mentoring extended beyond mere sharing of resources to include collaboration in planning and reflection, in counseling and psychological support through mutual motivation and positive reinforcement. However, a couple of mentees did not find peer mentoring helpful and relied only on the support of their mentors. Interestingly, an unplanned and unforeseen development was the formation of a mentor-initiated peer discussion group. Through this group and informally, mentors shared their experiences, in mentoring practices and their own teaching and provided mutual support. Interactions in this group also appeared, incidentally, to strengthen mentor motivation. One of the mentees also spoke about how peer mentoring had helped her through:

I did observe my peer during her class and I learned how she managed her class and how she does her teaching. We always have discussions concerning our pupils' abilities and how to encourage them to generate ideas. We found out from our discussions that the pupils we are teaching in general are so used to being spoon-fed.

Another mentee added that peer mentoring helped to strengthen her motivation, to take care of one another and to solve common problems in the teaching practice but "the most important thing is we motivated each other always and especially after we observed each other teaching. This is how we took care of each other". It should be noted that two mentees did not find peer mentoring helpful at all. One of them said she preferred to solve her problems for herself throughout the mentoring program. Although she sat with her peers, listened to their discussions and exchanges of views on their teaching experiences, she found that there was not much it could to do to help her.

Reflective practices and reflective journals: Two forms of reflective practices were conducted in the program: face-to-face reflective practices with mentors and reflective journal writing. Reflective practices in this study involved reflecting on their teaching practice together with teacher mentors face-to-face and this was typically intended to occur after each mentee's lesson and to include mentees' writing self-reflections on their experiences in their reflective journal throughout the mentoring program. In this mentoring program, elements of supervision including teaching observations, pre-and-post discussion were incorporated together with reflective practices. Most mentees (7-9) were satisfied with the reflective practices with their mentors even though they faced some difficulties, especially in the initial practice phase. Two mentees, however, reported that they were not satisfied because of the way reflection was conducted because the findings also show that the mentees generally believed that the quality of reflective practices varied. The mentees (in focus groups and interviews) generally agreed that one of the most important things they gained through reflective practices was self-awareness of weaknesses, strengths and their surroundings. Two of the mentees shared the importance of reflective practices in the mentoring program:

Reflective practice is essential. It is important because I realized that without it we would not know our faults, why things went wrong in our teaching and what we did exceptionally well. We discovered that we actually have the potentials to be good teachers.

I was not keen to do the reflective practices initially. I felt that there were just too many things to do during the practicum. But I realized that there were benefits from doing reflections. I found myself better in doing things after finding out my weaknesses, what I did wrong and finding solutions to rectify them.

Mentees also perceived that the timing of reflective practices discussions was important. They reported in focus groups that reflective practices were normally held after they had been observed by their mentors, sometimes immediately, but there were only brief, with longer, more formal reflections arranged later. Some reflective practices were also incorporated into other daily discussions, sometimes before lessons sometimes less formally and not always very productively.

It seems that the reflective journal was a sounding board for the mentees to voice their concerns as well as express their positive and negative emotions to their university supervisor in this study. Disclosing themselves openly to the mentors or with peers may 


\section{J. Social Sci., 8 (3): 350-363, 2012}

create a feeling of humiliation (malu) or being degraded as this is common in this local cultural context (Hamzah-Sendut et al., 1989). Trust was established with their university supervisor where they were able to confide their mentoring experience in the journal. Mentees (7-9) expressed that not only did it allow them to analyze their inner feelings but different emotions surfaced and they could express them in writing during the practice. One of the mentees also pointed out that, "writing down and being critical and thinking of solutions actually improved my teaching. It is not just teaching but it is a space where you can write your real thoughts. It also improved my writing ability". Use of these journals, where it was extensive enough, also proved therapeutic for some mentees and enhanced both their willingness and ability to write reflectively and analytically. However, some mentees were not keen to spend too much time on writing journals regarding such activity as a chore rather than educative.

Overall, the data show that both mentees benefited from doing the reflective practices but in different ways. It is apparent that the reflective practices assisted the mentees progressively in improving, enhancing and upgrading their teaching performance. As suggested by Ghaye et al. (1998), "reflection-on-practice takes experience and integrates it in particular ways" (1998, p. 16). The mentees were able to optimize their strengths by being proactive in integrating and using new ideas suggested by and discussed with mentors and was able to anticipate and plan more effectively to overcome difficulties. Planning and organization were enhanced by effective reflective practices with mentors. So too was the ability to accept constructive criticism after initial resistance.

Mentors also had positive experiences in the reflective practices, putting them back on track in their teaching approaches and strategies, discovering their strengths and weaknesses and improving themselves in their mentoring. With one exception the mentors indicated that they were able to carry out the reflective practices and they were satisfied with their performances in them. This finding corresponds with Hargreaves and Fullan (2000) and Cullingford (2006) suggestions that mentors learn from their mentees by developing new insights into their own and others' teaching, new relationships and a renewal of enthusiasm and commitment to their craft and career. Similarly, this finding also supports a finding by Balassa et al. (2003) that mentors gained in their ability to analyze their own teaching.

As indicated above, limitations on availability of participants, particularly teacher mentors, reduced the effectiveness of reflective practices in the program, although teacher mentors generally believed their contributions here were adequate. Where both groups of participants reported effective reflections, they were characterized by positive rapport and constructive outcomes for both participants: mentees reported positive developments in teaching and management skills, self-awareness, critical ability, mentors spoke of increased self-awareness, a sense of renewal and revaluing of their own teaching and management and their ability to use questions in probing and guiding mentees to think constructively about their work. This is also consistent with the suggestion of Schon (1987) that both reflection-in-action and reflection-on-action enable mentors and mentees to understand and improve their reflective practices.

Joint observations: Participants viewed joint observations and follow-up of mentee teaching by mentors and the university positively. Mentees were generally satisfied with the objectivity and fairness of assessment/grades according to SESD, UMS competency guidelines (SESD, UMS, Practicum Guidelines, 2005) through this process and with the positive results for their professional development. All the mentors (in focus group discussions) agreed that joint observations were beneficial because they provided a supporting environment for them, knowing that the university supervisor was there to discuss the mentees' progress, performances and the standardized teaching grades. Discussing and comparing their assessment with the university observer gave mentors confidence and, very importantly, they valued the acknowledgement by the university of their contribution in their role as a mentor. As one of the mentors said "... I never felt so honoured that my assessment and grades awarded to the mentee were acknowledged by the university..." Engaging in discussions about mentees' teaching during and after observations with the university supervisor allowed mentors to share their expertise in subject content with the mentor. Another mentor pointed out:

\section{We discussed the mentee's teaching performances, her weaknesses and strengths and how to improve her teaching as well the content and why such teaching strategies and teaching aids were used by the mentee as previously suggested for implementation}

Joint assessments were seen as more fair and standardized by both mentors and mentees and in awarding the grade mentor felt less isolated, more fully involved in the mentoring process generally. These 
positives for mentors were not immediate. Some, at least, were initially apprehensive and hesitant about the idea of joint observation but this was largely overcome with experience in the process. Overall, mentors felt acknowledged, honoured, valued as professionals by the university through joint observation and this appears to have increased and reinforced mentor commitment to the program. They further indicated that more formal recognition by the University of their input could take the form of a document (certificate), or remuneration or academic accreditation.

Mentoring roles and personalities: Basically in this study, the psychological mentoring support occurred across in all mentoring functions during the practicum. It emphasized developing positive personal qualities and attitudes to create an environment that is conducive to effective mentoring. Underpinning this support were establishing mentoring relationships, using interpersonal communicative skills, availability, selection criteria and matching of mentors, personal qualities and attitudes of mentors and mentees, mentoring roles and mentoring phases.

Most mentees agreed that their positive development in these professional areas was due to the support and advice provided by mentors in their roles as guide and advisor and to mentors' knowledge of content and pedagogical experience. Two mentees expressed disappointment that their mentors never really fulfilled these roles and one, at least, had to seek guidance and advice elsewhere. Other emerging mentor roles such as role model, partner and boss were also identified. The mentees described their mentors:

My teacher mentors played the role of a guide and advisor. These roles were essential in my teaching practice. I gained from the guidance and advice of my teacher mentors who were expert in their subjects. It provided me with support. They both carried out these roles very well

I considered my teacher mentor as a good role model. He gave me positive insights into being a good teacher. He was a good example and a positive model of a good teacher and I was grateful and lucky to have him as my teacher mentor. I learned a lot from just working with him and from what he has taught me. I am more confident now.

Initially, his actions were those of the boss because I was always waiting for his orders and him telling me what to do.
Some mentees in this study already considered their teacher mentors as their friends, with good relationships generally established, by the middle and late phases of the mentoring program. The factors credited by the mentees as contributing to these friendships were the positive qualities of the mentors such as caring and friendly attitudes as well as their interpersonal skills. Mentor-mentee friendship was seen as important in the effectiveness of more formal serious discussions or during observations. However, time constraint appears to have been a factor in the fulfillment of these roles by some mentors.

Establishing mentoring relationships and cultural factors: The emphasis of developing the mentoring relationship and communication was strong during the practicum. Incorporating interpersonal communication skills was essential to extend and sustain effective mentoring in a mentoring culture where this area was less emphasized. The building of effective mentoring relationships also depended greatly on the interpersonal skills of both participants. Where mentors brought warmth, diplomacy, sensitivity and positive approaches and reinforcement, the relationship flourished. This was particularly so when complemented by positive attitudes, receptiveness to advice, adaptability and flexibility in the mentee. To the extent that these qualities and skills were lacking in the relationship, particularly in the initial phase, mentoring was less effective. The most successful mentoring partnerships were collegial, collaborative and democratic. They also tended to be facilitated by a degree of informality, partly, at least related to the venues of contact outside the classroom and in planning discussions and reflective practices. One of the reasons given for this was that the informality was more conducive to maintaining a pleasant work environment with less tension. As two of the mentees pointed this out:

Our interactions seem to be better in informal places such as in the school canteen. Then we talked as we walked back to the staff room or classroom; along the corridor, we talked and discussed. Very informal I preferred informality because I felt at ease with my teacher mentors, like they were colleagues

My relationships actually happened informally such as sometimes meeting at the school canteen, outside the classrooms such as the corridors, or during the extracurricular activities 


\section{J. Social Sci., 8 (3): 350-363, 2012}

Mentors tended to value initiative and self-reliance in their mentees, particularly in relation to planning, reflection and resource acquisition and utilization. However, effective mentoring relationships and communication were not necessarily immediate but developed over time. Some cultural factors such as the importance of face, respect of the novice for the expert, the young for the elder, of hierarchy also appeared to play a part in the mentor-mentee relationship. Relative ages, mentor professional experience and gender were also factors in some mentoring relationships. Several mentors perceived a lack of commitment and a negative attitude in their mentees, resulting in an apparent unwillingness to co-operate in the mentoring process and constraining its effectiveness especially in seeking professional learning support and constraining mentoring relationship-building and interpersonal communication. Adjustments in personal qualities and attitudes were seen as a give and take way to overcome such constraints in this study. Such constraints also reflect the traditional culture of practicum supervision and assessment SESD, UMS context. Other cultural factors related to established practice, including criteria for and selection of mentors. In this program, as previously, mentors were simply appointed by the school, in at least two cases despite the reluctance of appointees and variations in their age and gender relative to those of mentees and their experience in teaching and mentoring. These factors impinged on the mentoring process for some participants, often negatively. This supported Hansman (2002) suggestion that mentors may be unwilling to help mentees when they are forced to become mentors.

Interpersonal communicative skills: The data here show that effective interpersonal communication skills are essential to positive relationships and communications between teacher mentors and mentees. More than half of the mentees (6-9) reported that their mentors used interpersonal communicative skills effectively to promote communications with them. In the focus group discussions, mentees noted such mentor skills as the ability, willingness and patience to listen and to use positive reinforcement. The majority of mentors (11-12) agreed with the mentees that they tried to use their interpersonal skills to communicate with their mentees. One of the mentors said:

For me, I considered everything possible to make sure that my mentee was comfortable in this practicum. I did not scold her. I used positive reinforcement when I talked to her to encourage and sustain her motivation. I made sure to make time to listen to her. I would just not talk to her in front of other people if I disagreed on something. I had to consider her feelings because I did not want to upset her.

It is apparent from the data that interpersonal communication skills go hand in hand with personality characteristics in influencing communications and relationships in mentoring. Where both mentor and mentee utilized such skills effectively, their relationship was fostered and enhanced. Some mentees found that they needed to apply such skills more fully to compensate for apparent weaknesses in those of their mentor and this was not always easy to do. To the extent that such skills were inadequate in either party their communication and relationship suffered.

Mentoring phases: Participants particularly, however, also identified these distinct mentoring phases during the practicum. The initial phase during the early weeks of the practicum was vital in the foundation and subsequent development of the mentoring relationship and its effectiveness. Other avenues to gain psychological support were through the development of the mentoring phases as both teacher mentors and mentees were in the process of establishing their mentoring relationships. For some, mentoring only became effective in the middle, even the final phases of the program. This supports the suggestion by Johnson (2007) that latter phases are when mentees have moved beyond being dependent and insecure; that they experience a steady increase in self-confidence and professional identity; that mentoring relationship becomes more reciprocal, characterized by mutual trust and more emotionally bonded through sharing ideas and values. Those whose positive relationships began earlier suggested that this was the most critical phase for successful mentoring. Another important positive factor here was the gradual withdrawal of scaffolding of mentor support as the program developed through the phases.

Mentees generally indicated that both professional learning support and psychological support were more needed in the initial phase of the mentoring process and that it takes time to establish mentoring relationships and communication. As pointed out by one of the mentees:

Yes, I feel that in the first few weeks, it was very hard to get along with them. Maybe it was because of our expectations and perceptions of them. It may also be personal. Maybe we judged them too early by looking at their facial expressions. I made it a point to talk to my teacher mentors and after 


\section{J. Social Sci., 8 (3): 350-363, 2012}

interacting with both my teacher mentors, I realized that they were okay.

Personal qualities of mentors and mentees also take time to develop in interaction as it takes time to be fully comfortable with one another. One of the mentors shared his experience:

At first my mentee was reluctant to approach me. She was very shy. That made building a mentoring relationship difficult in the initial phase of the mentoring program. I noticed this and I made it a point to go to her and talk to her. By me doing this, I observed that she came out of it. Gradually, this mode became familiar to her and after a while, I noticed she became accustomed to it. That was how the communication and relationship became closer.

All these elements were important contributing factors in creating environments that were conducive, secure and more relaxed for effective mentoring; to the extent that they were lacking here, the mentoring process was less effective. There were, however, some negative experiences: varying degrees of frustration and anxiety, particularly in the initial mentoring phase, from perceived lack of mentor support; lack of resources; unsatisfactory relationships and communication with mentors and some of these continued to varying degrees throughout the practicum.

\section{DISCUSSION}

Mentees valued professional psychological support from their teacher mentors. A variety of factors interacted in their impact on the effectiveness of the program in terms of the professional learning and psychological mentoring support. The study identified that mentees and also teacher mentors gained most important were: the phased development of the program itself; mentor selection; availability of time, venues and participants, particularly mentors; resource provision; and commitment, attitudes and communication and interpersonal skills of participants. Reflection and peer mentoring, mentor modeling and collaborative teaching and personal as well as professional mentoring in both informal and formal interactions were perceived to be important contributors to successful mentoring, though not all were practiced as comprehensively or as thoroughly as might have been here.

This study has important specific implications for SESD, UMS in teacher training. The outcome of the study will benefit teacher mentors and mentees in improving the mentoring process through providing more effective professional and psychological mentoring support and more effective mentoring relationships generally. SESD, UMS will be able to use the information from the study to plan more adequate and effective mentoring programs for the training of mentors and mentees and thereby improve the quality of the mentoring process in SESD, UMS and other higher education institutions and schools in Malaysia should benefit similarly. Partnerships and rapport between schools and SESD, UMS will also be improved and directly and, indirectly, the standard of education in schools and teacher education in Sabah will also be improved.

One of the great strengths of most mentoring programs is the voluntary commitment of dedicated individuals (Gay, 1994) expertise and experience in teaching and mentoring (if possible); interactive skills and communication; warmth, flexibility (especially in relation to cultural factors and traditional practice); and awareness of required mentoring roles and activities. Providing for more effective matching in terms of age and gender of mentors should be considered here if these are likely to affect the mentoring relationship. Selection should still be made by the school but with extensive input on the above criteria from the university. A particular factor to be considered here could be that of gender balance among mentors. The school should also be fully provided with information on the importance in mentoring of the provision of adequate resources, availability of mentors, providing adequate time and venues for formal and informal outof-classroom activities (planning, reflection,) and for observations of mentee and mentor teaching. The mentoring program should be seen as a joint enterprise, a partnership between school and university. As pointed out by Hall et al. (2008) "this can open the door for greater collaboration between universities and public schools as they work together to prepare better and more skilled teachers" (p. 330). Such collaboration could be facilitated by the appointment within the school, by a staff member with particular responsibility for the practicum and liaison with the university.

Further emphasis for all participants must be placed on the value and practices of collaborative teaching, mentee observations of mentor teaching and mutual planning and reflective practices, particularly in the early phases. Specific training in reflective practices should be part of workshop activities. Availability for such practices, especially of mentors, of time and appropriate-including informal - venues should be made a priority by participants, especially mentors and the 


\section{J. Social Sci., 8 (3): 350-363, 2012}

school. The importance of initiative-taking by mentees in relationship-building, resource- acquisition, adaptation of teaching and management strategies and reflection should also be emphasized. Mentees' reflective journal-writing should be a major component of the training program, perhaps with some practice exercises included and emphasized throughout the practicum, even as a compulsory component of the assessment and grading process. Peer mentoring, which tended to be a spontaneous development for the mentors here should be highlighted and encouraged, even formalized, for both groups of participants in the revised program, with specific provision made for it where possible. Initial experience in this could be provided in mentor brainstorm groups during training workshops.

All participants, however, should be made more aware of the importance of these in relation to democratic interaction and communication; adaptability, flexibility and openness to change; and collegial and collaborative mentoring relationships. Mentor roles must extend the emphasis on guidance and support in lesson planning, content, teaching and classroom management skills and school policies and culture, particularly in the early phases of the practicum. Partnership between school and university could be extended through increased university supervisor-mentor teacher collaboration (observations, evaluations,), perhaps with more university participation in the practicum generally. Mullen and Lick (1999) indicated that such partnership may offer and function as a form of shared purpose and commitment, joint inquiry, expanded guidance in professional development, shared power and could generate closer ties between schools and universities. Bradbury and Koballa (2008) also indicated that university supervisors can serve as "mediators who help facilitate discussions that promote clear articulations" of the expectations to foster mentoring relationships and communication (p. 2143) and to strengthen and expand university-school partnerships.

\section{CONCLUSION}

The major recommendation here is that the revised program of selection, training and implementation is put into practice. As recommended by Ewing et al. (2008), “... a truly effective mentoring program, whether formal or informal, should be designed, developed and implemented in an inclusive and wellresourced manner" (p. 296). Therefore, specific research could be conducted on mentor and mentee expectations of each other and of the mentoring process; cultural influences on mentoring relationships, particularly, perhaps, in the Malaysian context; ways of strengthening the school-university partnership; criteria for and methods of evaluating mentor and mentee performance in the practicum; infusing technology such as electronic mentoring to further enhance and diversify mentoring approaches; further understanding on issues embedded in mentoring relationships in order to provide better insights; further understanding of peer mentoring or group mentoring rather than mentoring on a one-to-one basis; a mentoring monitoring system for follow-up and for further improvement; and ways of further extending and developing the mentoring process in SESD, UMS in Malaysia and more widely.

\section{REFERENCES}

Anderson, E.M. and A.L. Shannon, 1988. Toward a conceptualization of mentoring. J. Teacher Educ., 39: 38-42. DOI: 10.1177/002248718803900109

Balassa, K., C. Bodoczky and D. Saunders, 2003. An impact study of the national Hungarian mentoring project in English language training. Mentoring Tutor.: Partnership Learn., 11: 307-320. DOI: 10.1080/1361126032000138346

Bradbury, L.U. and T.R. Koballa Jr, 2008. Borders to cross: Identifying sources of Tension in mentorintern relationships. Teach. Teacher Educ., 24: 2132-2145. DOI: 10.1016/j.tate.2008.03.002

Brooks, V., P.J. Sikes and C.T. Husbands, 1997. The Good Mentor Guide: Initial Teacher Education in Secondary Schools. 1st Edn., Open University Press, Buckingham, ISBN-10: 0335197582, pp: 188.

Cambourne, B., J. Kiggins and B. Ferry, 2003. Replacing traditional lectures, tutorials and exams with a Knowledge Building Community (KBC): A constructivist, problem-based approach to preservice primary teacher education. English Teaching: Practice Critique, 2: 24-48.

Cochran-Smith, M. and S.L. Lytle, 1999. Relationships of knowledge and practice: Teacher learning in communities. Rev. Res. Educ., 24: 249-305.

Cullingford, C., 2006. Mentoring in Education: An International Perspective. 1st Edn., Ashgate Publishing, Ltd., Aldershot, ISBN-10: 0754645770, pp: 218.

Evertson, C.M. and M.W. Smithey, 2000. Mentoring effects on Protégés' classroom practice: An experimental field study. J. Educ. Res., 93: 294301. DOI: $10.1080 / 00220670009598721$ 
Ewing, R., M. Freeman, S. Barrie, A. Bell and D. O'Connor et al., 2008. Building community in academic settings: The importance of flexibility in a structured mentoring program. Mentor. Tutoring: Partner. Learn., 16: 294-310. DOI: $10.1080 / 13611260802231690$

Feiman-Nemser, S., 2003. What new teachers need to learn. Educ. Leadership, 60: 25-29.

Furlong, J. and T. Maynard, 1995. Mentoring Student Teachers: The Growth of Professional Knowledge. 1st Edn., Routledge, London, ISBN-10: 0415113946, pp: 210.

Ganser, T., 1994. The impact of time and place in mentoring. University of Wisconsin-Whitewater.

Gay, B., 1994. What is mentoring? Educ. Train., 36: 47. DOI: 10.1108/00400919410062257

Ghaye, A., T. Ghaye and K. Ghaye, 1998. Teaching and Learning through Critical Reflective Practice. 1st Edn., David Fulton Publishers, London, ISBN-10: 1853465488, pp: 136.

Goldhammer, R., R.H. Anderson and R.J. Krajweski, 1980. Clinical Supervision: Special Methods for the Supervision of Teachers. 2nd Edn., Holt, Rinehart and Winston, New York, ISBN-10: 0030465710, pp: 216.

Hall, K.M., R.J. Draper, L.K. Smith and R.V. Bullough Jr, 2008. More than a place to teach: Exploring the perceptions of the roles and responsibilities of mentor teachers. Mentor. Tutor.: Partner. Learn., 16: 238-345. DOI: 10.1080/13611260802231708

Hamzah-Sendut, H., J. Madsen and G.T.S. Thong, 1989. Managing in a Plural Society. 1st Edn., Longman, Singapore, ISBN-10: 9971899736, pp: 229.

Hansman, C.A., 2002. Critical Perspectives on Mentoring: Trends and Issues. 1st Edn., ERIC Clearinghouse on Adult, Career Vocational Education, Columbus, OH, pp: 63.

Hargreaves, A. and M. Fullan, 2000. Mentoring in the new millennium. Theory Pract., 39: 50-56. DOI: 10.1207/s15430421tip3901_8

Idris, N., 1999. An overview of mentoring programmes in six schools in Malaysia. Proceedings of the 2nd Regional Conference on Tutoring and Mentoring Perth, May 5-5, Google Scholar Database, Western Australia.

Ismail, M. and L. Arokiasamy, 2007. Exploring mentoring as a tool for career advancement of academics in private higher education institutions in Malaysia. J. Inter. Soc. Res., 1: 135-148.

Ismail, N.B.H., 2001. The mentoring processes of primary ESL student teachers in Malaysia. 1st Edn., The University of Exeter, United Kingdom.
Johnson, W.B., 2007. On Being a Mentor: A Guide for Higher Education Faculty. 1st Edn., Routledge, New Jersey, ISBN-10: 0805848975, pp: 260.

Jonson, K.F., 2008. Being an Effective Mentor: How to Help Beginning Teachers Succeed. 2nd Edn., Corwin Press, Thousands Oaks, California, ISBN10: 1412940621, pp: 206.

Kajs, L.T., 2002. Framework for designing a mentoring program for novice teachers. Mentor. Tutor.: Partner. Learn., 10: 57-69. DOI: 10.1080/13611260220133153

Kilburg, G.M., 2007. Three mentoring team relationships and obstacles encountered: A school-based case study. Mentor. Tutor.: Partner. Learn., 15: 293-308. DOI: 10.1080/13611260701202099

Kunjambu, B., H.T. Chung, C.Y. Hassan, N.A. Abdullah and K.A. Sani et al., 2002. Perceptions of semester 6teacher trainees towards the mentoring practices of the school mentors and college tutors during the practicum: A comparative study. J. Pendidkan ILTIZAM, 1.

Ligadu, C., M. Daud and R. Talin, 2001. Quality of Mentoring: Perceptions of mentors and mentees during the practicum. Proceedings of the World Conference of Instruction and Curriculum, Sept. 1418, Universita Distancia, Madrid, Spain.

McIntyre, D. and H. Hagger, 1996. Mentors in Schools: Developing the Profession of Teaching. 1st Edn., David Fulton Publishers, London, ISBN-10: 1853464112, pp: 169.

McIntyre, D., H. Hagger and M. Wilkin, 1994. Mentoring: Perspectives on School-Based Teacher Education. 1st Edn., Routledge, London, ISBN-10: 0749415339, pp: 250.

Moore, S.B. and R.L. Wells, 1999. Interdepartmental collaboration in Teacher education. Inter. School Clin., 34: 288-231.

Mullen, C.A. and D.W. Lick, 1999. New Directions in Mentoring: Creating a Culture of Synergy. 1st Edn., Routledge, London, ISBN-10: 075071011X, pp: 271.

Narayanasamy, S., 1995. The assistance provided by the mentor teachers to protégés in the final practicum program in selected primary schools in Petaling Jaya and the needs for professional assistance as perceived by those protégés. MS.c Thesis, University of Houston, Kuala Lumpur.

Ng, C.M. and I. Osman, 1995. Masalah yang dihadapi oleh guru pelatih semasa menjalankan praktikum1 Laporan Penyelidikan Maktab Perguruan Ilmu Khas: Kuala Lumpur. "Problems encountered by the cooperating teachers in the context of supervision during the school practicum: in Tempawan. Maktab Perguruan Ilmu Khas, 7: 45-52. 
Rowley, J.B., 1999. The good mentor. Educ. Leader., 56: $20-22$.

Salleh, N.M. and C.L. Hoon, 1997. Mentoring guru pelatih dalam konteks permuafakatan di antara institusi perguruan and sekolah (mentoring student teachers in the context of partnership between teacher training colleges and schools). University of Malaya, Kuala Lumpur.

Salleh, N.M., 1999. Kearah mengekalkan usahasama ipg dan sekolah. kertas kerja yang dibentangkan di seminar kebangsaan penyelarasan pendidikan guru. University of Malaya, Kuala Lumpur.

Sanggura, L.H.A., 1998. The impact of mentoring on teachers' professional development. J. Pendidikan TIGAENT, 2: 16-32.

Schon, D., 1987. Educating the Reflective Practitioner: Toward a New Design for Teaching and Learning in the Professions. 1st Edn., Jossey-Bass, San Francisco, CA., pp: 355.

Stansbury, K. and J. Zimmerman, 2000. Lifelines to the Classroom: Designing Support for Beginning Teachers. 1st Edn., WestEd, San Francisco, CA., pp: 15.
Tan, H.L. and A.A. Hamid, 1992. Penyeliaan Dalam Latihan mengajar: Peranan Dalam Meningkatkan Kualiti Guru Permulaan (Ways to Improve Quality of Beginning Teacher. J. Pendidikan, Kementerian Pendidikan Malaysia.

Tickle, L., 1991. New Teachers and the emotions of learning teaching. Cambridge J. Educ., 21: 319329. DOI: $10.1080 / 0305764910210306$

Tuah, A.B., 2003. The headmaster-as-a-mentor: A mentoring model for rural primary schools of Sarawak. J. Pendidikan MPBL. Jilid 4.

Villani, S., 2002. Mentoring Programs for New Teachers: Models of Induction and Support. 1st Edn., Corwin Press, Thousand Oaks, CA., ISBN10: 0761978690, pp: 244.

Wang, J. and S.J. Odell, 2002. Mentored learning to teach according to standards-based reform: A critical review. Rev. Educ. Res., 72: 481-546.

Yost, R., 2002. "I think i can": Mentoring as a means of enhancing teacher efficacy. Clear. House, 75: 195-197. 